\title{
Filarial Hydrocele as Cause of Temporary Impotence in an Alleged Accused of Sexual Assault-A Case Report
}

\author{
Dr. Bhavish Prakash $\mathrm{MD}^{1 *}$, Dr. Sachin Sonvane $\mathrm{MD}^{2}$, Dr. Rajesh Sukhadeve MD ${ }^{3}$, Dr. Manoj B Parchake MD ${ }^{1}$
}

${ }^{1}$ Assistant Professor, Department of Forensic Medicine, Seth Gordhandas Sunderdas Medical College \& King Edward Memorial Hospital Parel Mumbai 400012, India

${ }^{2}$ Associate Professor, Department of Forensic Medicine, HBTMC \& Dr. R. N. Cooper Municipal General Hospital, Mumbai, Maharashtra, India

${ }^{3}$ Professor and Head, Department of Forensic Medicine HBTMC \& Dr. R. N. Cooper Municipal General Hospital, Mumbai, Maharashtra, India

DOI: $10.36347 /$ sjams.2020.v08i09.037

| Received: 16.09.2020 | Accepted: 23.09.2020 | Published: 28.09.2020

*Corresponding author: Dr. Bhavish Prakash

Abstract

Impotence is the inability to perform, or permit the performance of, the act of sexual intercourse, whereas sterility is the inability to impregnate/get impregnated. Hydrocele is an accumulation of fluid in the tunica vaginalis layer in the scrotum that causes it to swell. Alleged accused of sexual assault 52 year old brought for examination in hospital. On examination, giant hydrocele was noted and later confirmed by urologist and further investigation. This case report highlights the importance of detailed examination and how to frame opinion in such cases and sample collection.

Keywords: Filarial, Hydocele, Temporary Impotence, Sexual Assault.

Copyright @ 2020: This is an open-access article distributed under the terms of the Creative Commons Attribution license which permits unrestricted use, distribution, and reproduction in any medium for non-commercial use (NonCommercial, or CC-BY-NC) provided the original author and source are credited.

\section{INTRODUCTION}

Impotence is the inability to perform, or permit the performance of, the act of sexual intercourse, whereas sterility is the inability to impregnate/get impregnated [1]. Hydrocele is an accumulation of fluid in the tunica vaginalis layer in the scrotum that causes it to swell. There were 26.79 million cases of hydrocele worldwide and $48 \%$ of these cases are in India [2]. However, slight information is available from India, particularly on disability due to hydrocele, except for a few studies on productivity [3-6]. A large hydrocele or scrotal hernia, elephantiasis, phymosis, paraphymosis and adherent prepuce may cause temporary impotence by mechanical obstruction to coitus, as these conditions can be remedied by proper surgical treatment. Marked diseases of penis or of the testicles, such as orchitis following mumps, syphilis, tuberculosis, etc. may lead to impotence or sterility or both [1].

Lymphatic filariasis (LF), the second leading cause of permanent and long-term disability [7], affects 120 million people globally [8]. It is a mosquito-borne parasitic disease caused by Wuchereria bancrofti, which resulted in for approximately $90 \%$ of all LF cases, followed by Brugia malayi and Brugia timoti. India contributes about $40 \%$ of the total worldwide burden of LF. In India, a total of 554 million people are at risk of infection, and there are approximately 21 million people with symptomatic LF and 27 million asymptomatic microfilaria carriers [9]. The manifestations of disease are mostly irreversible and a cause of psychological and socioeconomic problems for patients and often their families [10, 11].

\section{CASE History}

The alleged accused 52 years old male, married since 28 years, father of 6 children, was brought for complete medical examination under sec 377,323 IPC and sec 4, 6, 8, 12 of POCSO Act on 14 sept 2019 in our department. After taking his consent and identification, history of alleged incidence was taken from him. Alleged incidence was on 10 sept 2019 but the negative history given by the alleged accused was not matching with statement of 7-8 years old male survivor's mother. As per alleged accused, he is not sexually active since last 5 months. No surgical or any medical history was given.

Alleged accused was alert, vitals were stable, averagely built, and no evidence of any fresh injuries was present. No evidence of any developmental defect or gynaecomastia was present. No systemic abnormality was detected on examination.

On local examination a huge hydrocele was noticed with vertical diameter, horizontal diameter and circumference of $34 \mathrm{cms}, 26 \mathrm{cms}$ and $58 \mathrm{cms}$ respectively. Penis root up to tip of penis and scrotum 
were completely merged in the hydrocele. There was a gradual increase in size since last 5 years. Nail clippings, pubic hair and blood for DNA analysis were collected. Alleged accused was sent to surgery dept. for conformation and treatment of hydrocele. Diagnosis was confirmed by sonography as filariasis with gross hydrocele. Opinion regarding impotency was reserved till complete urological examination reports are made available.

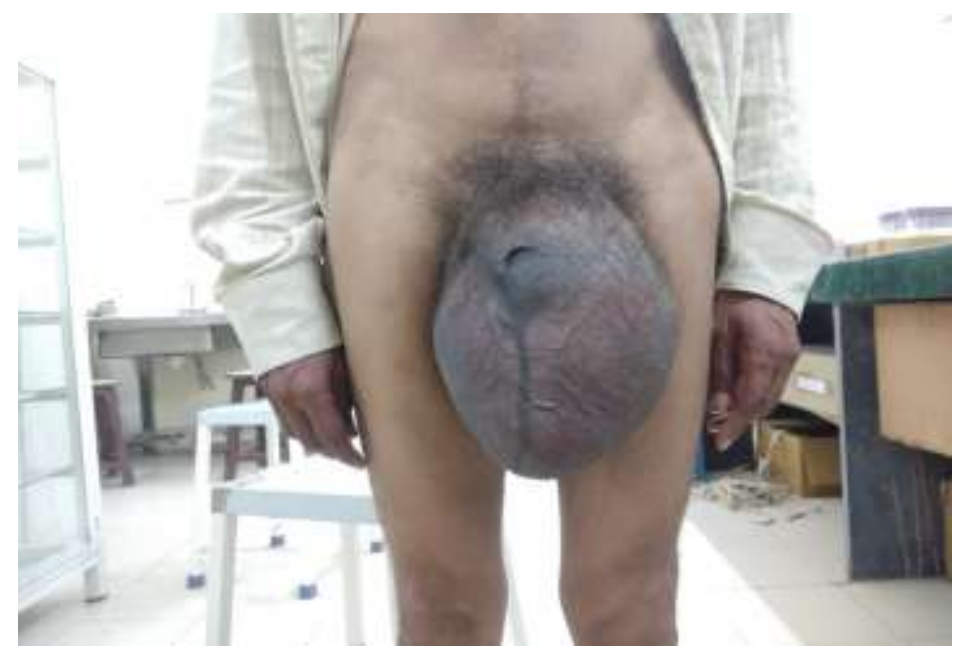

Fig-1: Prominent blood vessels over surface of hydrocele

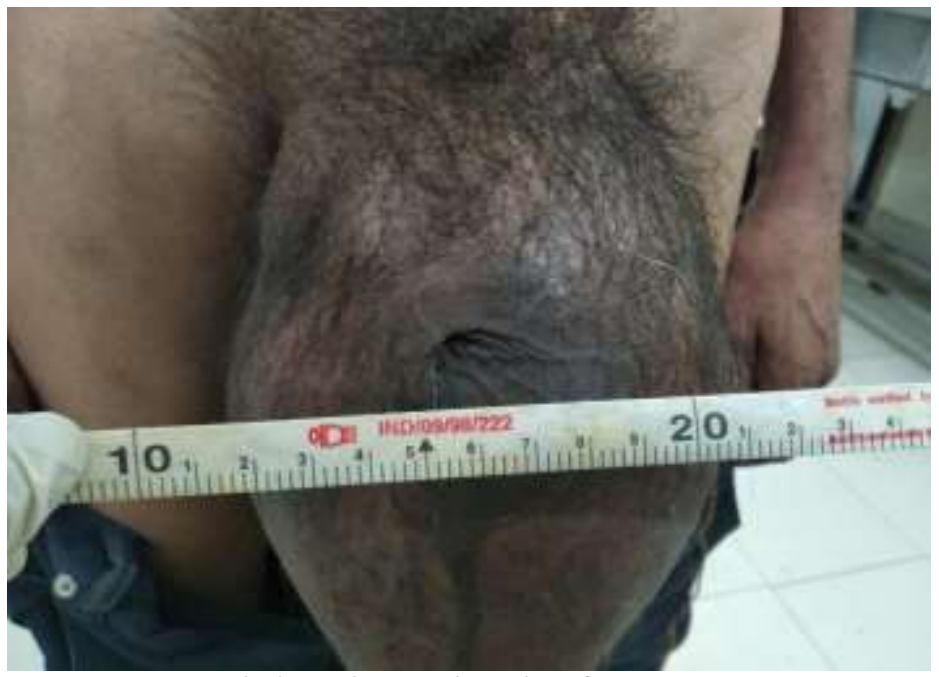

Fig-2: Horizontal dimension of hydrocele

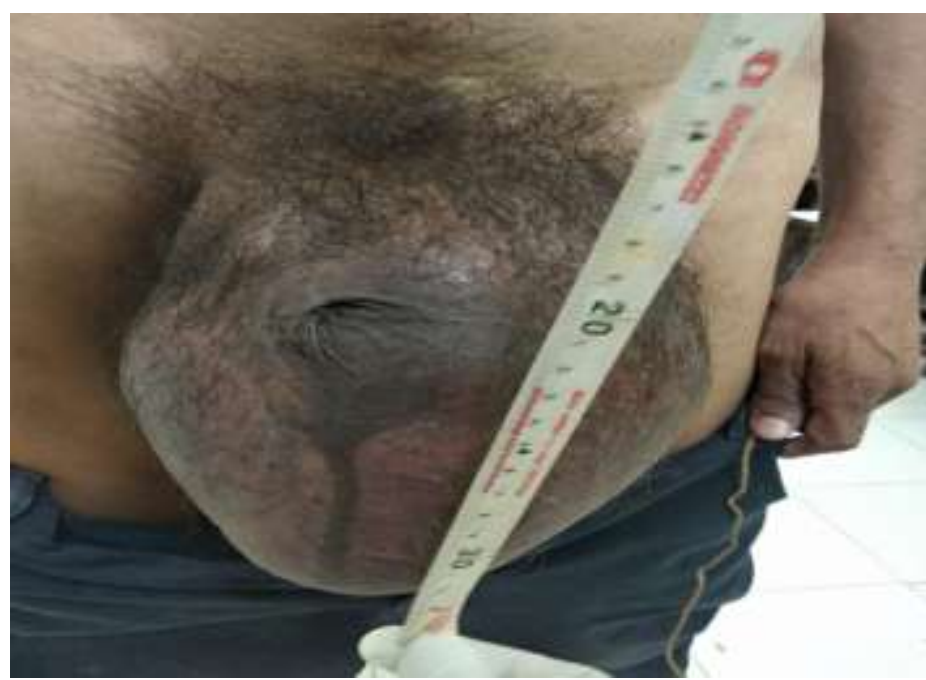

Fig-3: Vertical dimension of hydrocele 


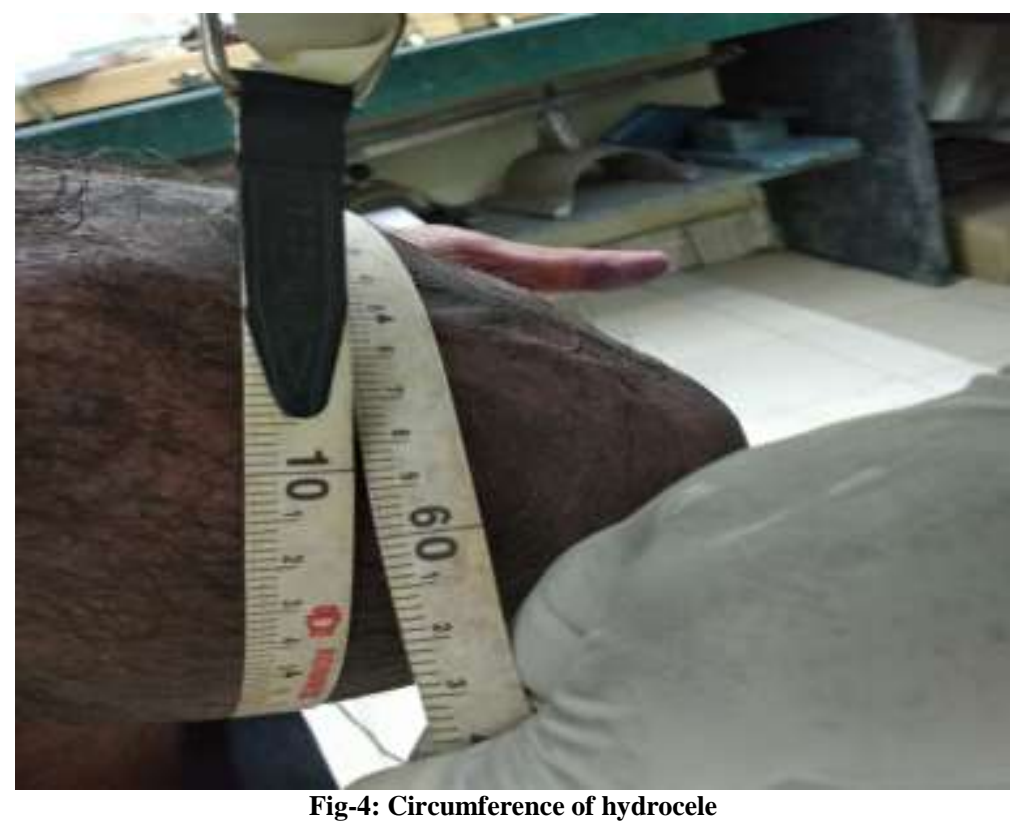

\section{DISCUSSION}

Hydrocele is a swelling due abnormal collection of clear fluid. Filarial hydrocele is common in endemic areas of tropics and sub-tropics which is caused by flarial worms Wuchereria bancrofti and Brugia malayi. This may cause thickening of scrotal skin and blockage of lymph channels. A large hydrocele may cause temporary impotence by mechanical obstruction to coitus and this condition can be remedied by proper surgical treatment. It can complicate as elephantiasis which is also a temporary local cause of impotence. Wound healing is slow and infections are more common in cases of filarial hydrocele. Internal scrotal bleeding can also be present which is not visible on local examination. Untreated Hydroceles can lead to infection of the fluid and testicular atrophy.

As per Babu et al., [12] majority of patient (94\%) express incapability to perform sexual intercourse and wives of the patients noted dissatisfaction in sexual activity. In our case, accused of sexual assault on child has been suffering from hydrocele due filariasis. Our case report highlights the importance of detail examination of accused suffering from hydrocele and samples collection from genital parts in such cases. Criminal amendment 2013 includes not only penile penetration but also fingering or insertion of any object in vagina. Hence it is very important to mention in opinion regarding hydrocele as cause of temporary impotence and also to give opinion on another aspect such as fingering or insertion of object in such cases. In our case report we have given opinion after availability of urological opinion. Final opinion is given as "findings are suggestive of temporary impotence due to hydrocele however possibility of fingering cannot be ruled out."

\section{Conclusion}

1. History regarding rapidity of onset impotence, its duration, any drug history or chronic illness along with local examination is important aspect for assessment of risk factors and to rule out causes other than local causes of impotence.

2. The present case suggests that hydrocele is not only the cause of temporary impotence but could be the evidence of sexual inactivity.

3. Hydrocele is not the limitation for evidence collection from genital region in recent alleged cases of sexual assault.

4. No evidence of any fresh injuries over the genital region does not rule out internal bleeding in scrotal region or infection of hydrocele.

5. Urological investigations should be done before giving any opinion regarding impotency as not all cases of hydrocele presents with temporary impotence.

\section{REFERENCE}

1. Vij K. Textbook of Forensic Medicine and Toxicology Principles and practice. $5^{\text {th }}$ ed. Elsevier:2011

2. Michael E, Bundy DA, Grenfell BT. Re-assessing the global prevalence and distribution of lymphatic filariasis. Parasitology. 1996; 112(Pt 4):409-428.

3. Ramaiah KD, Guyatt H, Ramu K, Vanamail P, Pani SP, Das PK. Treatment costs and loss of work time to individuals with chronic lymphatic filariasis in rural communities in south India. Trop Med Int Health. 1999;4:19-25

4. Babu BV, Nayak AN, Dhal K, Acharya AS, Jangid PK, Mallick G. The economic loss due to treatment costs and work loss to individuals with chronic 
lymphatic filariasis in rural communities of Orissa, India. Acta Trop. 2002; 82:31-38.

5. Ramaiah KD, Kumar KN, Ramu K, Pani SP, Das PK. Functional impairment caused by lymphatic filariasis in rural areas of south India. Trop Med Int Health. 1997; 2:832-838.

6. Babu BV, Swain BK, Rath K. Impact of chronic lymphatic filariasis on quantity and quality of productive work among weavers in an endemic village from India. Trop Med Int Health. 2006; 11:712-717.

7. World Health Organization. World health report. Geneva: World Health Organization; 1995.

8. Michael E, Bundy DA, Grenfell BT. Re-assessing the global prevalence and distribution of lymphatic filariasis. Parasitology. 1996; 112(Pt 4):409-428.
9. Sabesan S, Palaniyandi M, Das PK, Michael E. Mapping of lymphatic filariasis in India. Ann Trop Med Parasitol. 2000; 94:591-606.

10. Gyapong JO, Gyapong M, Evans DB, Aikins MK, Adjei S. The economic burden of lymphatic filariasis in northern Ghana. Ann Trop Med Parasitol. 1996; 90:39-48.

11. Dreyer G, Noroes J, Addiss D. The silent burden of sexual disability associated with lymphatic filariasis. Acta Trop. 1997;63:57-60.

12. Babu BV, Mishra S, Nayak AN. Marriage, sex, and hydrocele: an ethnographic study on the effect of filarial hydrocele on conjugal life and marriageability from Orissa, India. PLoS Negl Trop Dis. 2009 Apr 21;3(4):e414. 